\title{
Antagonism Between Saturated and Unsaturated Fatty Acids in ROS Mediated Lipotoxicity in Rat Insulin-Producing Cells
}

\author{
Wiebke Gehrmann Wiebke Würdemann Thomas Plötz Anne Jörns \\ Sigurd Lenzen Matthias Elsner \\ From the Institute of Clinical Biochemistry, Hannover Medical School, Hannover, Germany
}

\section{Key Words}

Lipotoxicity • Type 2 diabetes mellitus • Oxidative stress $•$ Hydrogen peroxide $・$ Peroxisome • Palmitic acid • Oleic acid

\begin{abstract}
Background/Aims: Elevated levels of non-esterified fatty acids (NEFAs) are under suspicion to mediate $\beta$-cell dysfunction and $\beta$-cell loss in type 2 diabetes, a phenomenon known as lipotoxicity. Whereas saturated fatty acids show a strong cytotoxic effect upon insulin-producing cells, unsaturated fatty acids are not toxic and can even prevent toxicity. Experimental evidence suggests that oxidative stress mediates lipotoxicity and there is evidence that the subcellular site of ROS formation is the peroxisome. However, the interaction between unsaturated and saturated NEFAs in this process is unclear. Methods: Toxicity of rat insulin-producing cells after NEFA incubation was measured by MTT and caspase assays. NEFA induced $\mathrm{H}_{2} \mathrm{O}_{2}$ formation was quantified by organelle specific expression of the $\mathrm{H}_{2} \mathrm{O}_{2}$ specific fluorescence sensor protein HyPer. Results: The saturated NEFA palmitic acid had a significant toxic effect on the viability of rat insulin-producing cells. Unsaturated NEFAs with carbon chain lengths $>14$ showed, irrespective of the number of double bonds, a pronounced protection against palmitic acid induced toxicity. Palmitic acid induced $\mathrm{H}_{2} \mathrm{O}_{2}$ formation in the peroxisomes of insulin-producing cells. Oleic acid incubation led to lipid droplet formation, but in contrast to palmitic acid induced neither an ER stress response nor peroxisomal $\mathrm{H}_{2} \mathrm{O}_{2}$ generation. Furthermore, oleic acid prevented palmitic acid induced $\mathrm{H}_{2} \mathrm{O}_{2}$ production in the peroxisomes. Conclusion: Thus unsaturated NEFAs prevent deleterious hydrogen peroxide generation during peroxisomal $\beta$-oxidation of long-chain saturated NEFAs in rat insulin-producing cells.
\end{abstract}

Copyright $\odot 2015$ S. Karger AG, Basel

Prof. Sigurd Lenzen

KARGER 125
Institute of Clinical Biochemistry Hannover Medical School 30623 Hannover (Germany) Tel. +49/511/5326525, Fax +49/511/5323584, E-Mail lenzen.sigurd@mh-hannover.de 


\section{Cellular Physiology Cell Physiol Biochem 2015;36:852-865

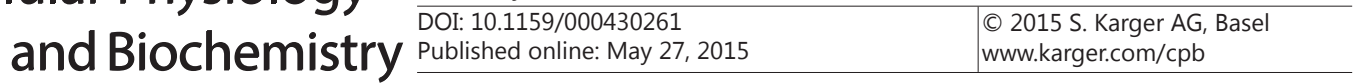 \\ Gehrmann et al.: Oleic Acid Reverses Lipotoxicity}

\section{Introduction}

The prevalence of type 2 diabetes mellitus increases in parallel to the increasing rate of obesity [1], which is one of the major risk factors for diabetes development and usually accompanied by hyperlipidaemia [2-4]. Hyperlipidaemia, in turn, is typically associated with elevated non-esterified fatty acid (NEFA) plasma concentrations, which are supposed to contribute to insulin resistance, impaired insulin secretion due to a progressive decline in pancreatic $\beta$-cell function and mass, a phenomenon called lipotoxicity [5-7]. In vitro studies have shown that long-chain saturated NEFAs can induce apoptosis [8-11]. This has been considered, at least in part, to be mediated by the induction of the unfolded protein response (UPR) [12]. However, other observations indicate that the induction of this ER-stress response may not be solely responsible for lipotoxicity [13]. Other studies suggest that the generation of ROS during the metabolism of NEFAs can mediate their deleterious action. This concept comprises ROS formation at complex I and III in the electron transport chain as a result of an overloaded mitochondrial fatty acid metabolism [14-17]. In a recent study we put forward a new concept in which the $\beta$-oxidation of saturated long-chain fatty acids in the peroxisome was suggested to be responsible for ROS formation and death of pancreatic $\beta$-cells [9]. Interestingly, unsaturated long-chain fatty acids have been reported not to be toxic $[8,18,19]$. Moreover, unsaturated fatty acids efficiently antagonized the toxic action of saturated NEFAs [19-22]. Therefore, we analysed in the present study the mechanism underlying this protective action with special emphasis upon the role of peroxisomal ROS formation.

\section{Materials and Methods}

\section{Materials}

RPMI 1640 tissue culture medium, penicillin and streptomycin were purchased from Biochrom (Berlin, Germany). Tissue culture plates were obtained from Greiner Bio-One (Frickenhausen, Germany). Custom designed PCR primers and Taqman probes were synthesized from Life Technologies (Karlsruhe, Germany). Palmitoleic acid was obtained from Larodan (Malmö, Sweden). All other chemicals were purchased from Sigma-Aldrich (Taufkirchen, Germany).

Tissue culture of insulin-producing cells

RINm5F insulin-producing cells were cultured in RPMI 1640 medium supplemented with $10 \mathrm{mM}$ glucose, $10 \%$ (v/v) foetal calf serum (Biowest, Nuaillé, France), penicillin, and streptomycin in a humidified atmosphere at $37^{\circ} \mathrm{C}$ and $5 \% \mathrm{CO}_{2}$, as described previously [23]. RINm5F cell clones that overexpressed catalase either in the mitochondria or in the peroxisomes were generated as described previously [24, 25]. Cellular expression of catalase was analysed by enzyme activity measurement.

NEFAs (Sigma, St. Louis, MO, USA) were dissolved in $90 \%$ ethanol by heating to $60^{\circ} \mathrm{C}$ and used at different concentrations in RPMI 1640 (PAN, Aidenbach, Germany) with $1 \%$ foetal calf serum and a final BSA/NEFA ratio of 2\%/1 mM (defined NEFA free BSA, MP Biomedicals, Eschwege, Germany). All untreated wells received the same amount of solvent and BSA. This procedure did not cause a significant decrease in viability in the absence of fatty acids [26].

Rat islet isolation and culture

Pancreatic islets were isolated from 250-300 g adult male Lewis rats by collagenase digestion, separated by Ficoll gradient, and handpicked under a stereo microscope. Isolated islets were cultured on extracellular matrix (ECM)-coated plates $(35 \mathrm{~mm}$ ) (Novamed, Jerusalem, Israel, the ECM being derived from bovine corneal endothelial cells) in RPMI 1640 medium containing $5 \mathrm{mM}$ glucose, $10 \%$ FCS, penicillin, and streptomycin at $37{ }^{\circ} \mathrm{C}$ in a humidified atmosphere of $5 \% \mathrm{CO}_{2}$ [9]. The islets were cultured for 7-10 days on the ECM plates to adhere and spread before they were infected with HyPer-Peroxi lentivirus or treated with palmitic acid.

\section{KARGER}




\section{Cellular Physiology Cell Physiol Biochem 2015;36:852-865 \begin{tabular}{l|l|l}
\hline DOI: 10.1159/000430261 & C 2015 S. Karger AG, Basel
\end{tabular} \begin{tabular}{l|l|} 
and Biochemistry Published online: May 27, 2015 & www.karger.com/cpb \\
\hline
\end{tabular}

\section{Assessment of cell viability}

RINm5F insulin-producing cells were seeded at $2.5 \times 10^{4}$ cells/well in $100 \mu \mathrm{l}$ culture medium on 96well plates and allowed to attach for $24 \mathrm{~h}$ before they were incubated at $37^{\circ} \mathrm{C}$ with NEFAs for $24 \mathrm{~h}$. Cell viability was then determined by a microplate-based MTT assay (3-(4,5-dimethylthiazol-2-yl)-2,5-diphenyl tetrazolium bromide, Serva, Heidelberg, Germany) [27].

\section{Caspase assay}

RINm5F insulin-producing cells were seeded at $1 \times 10^{6}$ cells on $6 \mathrm{~cm}$ tissue culture dishes and treated after $24 \mathrm{~h}$ with NEFAs. The cells were trypsinized after $24 \mathrm{~h}$ exposure to different NEFAs and stained for active caspases with the FITC-conjugated monoclonal active caspase-3 antibody apoptosis kit I (BD Biosciences Pharmingen, San Diego, CA). For the detection of caspase-8, caspase-9 or caspase-12 staining kits from PromoKine (Heidelberg, Germany) were used according to the manufacturer's protocols. The cells were analysed by flow cytometry at the FL- 1 channel $(488 / 527 \mathrm{~nm})$ for active caspase-3, -9 , and -12 or at the FL-2 channel ( $488 / 575 \mathrm{~nm}$ ) for active caspase- 8 with the CyFlowML cytometer (Partec, Münster, Germany). The portion of caspase-negative cells within the untreated cell population was gated and, on the basis of this gate, the portion of cells in which the caspases were activated after NEFA treatment could be determined.

\section{Electron microscopy}

Small RINm5F cell pellets treated for $24 \mathrm{~h}$ with different fatty acids were fixed in $2 \%$ para-formaldehyde and $2.5 \%$ glutaraldehyde in $0.1 \mathrm{M}$ cacodylate buffer, $\mathrm{pH} 7.3$, postfixed in $1 \% \mathrm{OsO}_{4}$ and finally embedded in Epon (Agar Scientific, Cambridge, UK) for electron microscopic analysis to identify changes in the different cell organelles [28]. Thin sections were contrast-stained with saturated solutions of lead citrate and uranyl acetate.

Measurement of ROS by DCF-DA fluorescence

To detect overall oxidative stress, $2.5 \times 10^{4}$ cells were seeded on 96-well black plates and cultured for $24 \mathrm{~h}$. The cells were then pre-incubated with $10 \mu \mathrm{M}$ DCF-DA (2,7-dichlorofluorescein diacetate, SigmaAldrich) for $30 \mathrm{~min}$ at $37^{\circ} \mathrm{C}$. Thereafter, medium containing DCF-DA was replaced with fresh medium with or without NEFAs. After $24 \mathrm{~h}$ incubation, the plates were analysed at 480/520 nm excitation/emission using the fluorescence reader Victor ${ }^{2} 1420$ Multilabel Counter (Perkin Elmer, Wiesbaden, Germany) [29]. Thereafter cell viability was determined by MTT assay and DCF fluorescence was normalized to the viability.

\section{Cloning of the HyPer-Peroxi vector}

To construct the expression vector for the HyPer-Peroxi protein that allowed detection of peroxisomegenerated $\mathrm{H}_{2} \mathrm{O}_{2}$, the peroxisome target signal 1 (PTS-1) [30,31] was fused to the 3'-end of the HyPer cDNA by PCR using composite primer (HyPer-PTS1-Xbal-fw (5'-TATCTAGACGCCACCATGGAGATGGCAA-3') and HyPer-PTS1-Bsp119I-rv (5'-GCTTCGAATTACAGCTTGGAAACCGCCTGTTTTAAAAC-3')) and the pHyperdCyto plasmid as template. Thereafter, the HyPer-Peroxi cDNA was subcloned into the XbaI/Bsp119I site of the pLenti6/V5-MCS plasmid [32].

\section{Preparation of lentiviruses}

To express the HyPer-Peroxi protein in the insulin-producing RINm5F cell line, lentivirus was prepared [33]. $5 \times 10^{6}$ 293FT cells were transfected with the packaging plasmid pPAX2 (37.5 $\left.\mu \mathrm{g}\right)$, the envelope plasmid pcDNA3-MDG $(7.5 \mu \mathrm{g})$, and the transfer plasmid pLenti6/V5-MCS-HyPer-Peroxi $(25 \mu \mathrm{g})$ by calcium phosphate precipitation. The virus particles were harvested from the culture medium $48 \mathrm{~h}$ later and purified by ultracentrifugation $(70,000 \mathrm{~g}, 2 \mathrm{~h})$. The virus titers $\left(3-5 \times 10^{7}\right.$ infectious particles) were quantified by Taqman qPCR assay as described [34].

\section{Lentiviral transduction}

The RINm5F-control, RINm5F-Cat, and RINm5F-MitoCat [24] cell lines were infected with HyPerPeroxi lentivirus at a MOI of 10 . The cells were selected for HyPer expression using blasticidin $(1 \mu \mathrm{mol} / \mathrm{L})$.

Analysis of $\mathrm{H}_{2} \mathrm{O}_{2}$ generation using HyPer proteins

RINm5F cells $\left(1 \times 10^{5}\right)$ that overexpressed HyPer-Peroxi were seeded onto black 24-well glass-bottom plates (Zellkontakt, Nörten-Hardenberg, Germany). Cells were cultured for $24 \mathrm{~h}$ and then exposed to 100 


\section{Cellular Physiology Cell Physiol Biochem 2015;36:852-865 \\ \begin{tabular}{l|l}
\hline DOI: 10.1159/000430261 & (C) 2015 S. Karger AG, Basel
\end{tabular} \\ \begin{tabular}{l|l} 
and Biochemistry Published online: May 27, 2015 & www.karger.com/cpb
\end{tabular} \\ Gehrmann et al.: Oleic Acid Reverses Lipotoxicity}

$\mu \mathrm{M}$ palmitic acid, $100 \mu \mathrm{M}$ oleic acid or a mixture of palmitic and oleic acid (100 $\mu \mathrm{M}$ each) for another $24 \mathrm{~h}$. Live cell imaging was performed using a CFP-YFP dual filter (excitation, $427 \mathrm{~nm}$ and $504 \mathrm{~nm}$; emission, 520 $\mathrm{nm}$ ) with a cell ${ }^{\mathrm{R}}$ /Olympus IX 81 inverted microscope system (Olympus, Hamburg, Germany). CellR software (Olympus) was used for imaging and analysis.

To determine $\mathrm{H}_{2} \mathrm{O}_{2}$ production, changes in the fluorescence ratios of RINm5F, RINm5F-Cat and RINm5F-MitoCat cells that overexpressed HyPer-Peroxi were quantified spectrofluorometrically. Those cells were seeded at $2.5 \times 10^{4}$ cells per well onto black 96 -well plates and cultured for $24 \mathrm{~h}$. The fluorescence ratio (excitation $427 \mathrm{~nm}$ and $475 \mathrm{~nm}$, emission $520 \mathrm{~nm}$ ) was measured immediately before and after $24 \mathrm{~h}$ treatment with NEFAs.

\section{Lipid droplet staining with Oil Red 0}

RINm5F cells were cultured for $24 \mathrm{~h}$ and afterwards exposed to $100 \mu \mathrm{M}$ of different unsaturated NEFAs with different chain lengths and different numbers of double bonds for another $24 \mathrm{~h}$. Cells were trypsinised and fixed in paraformaldehyde for $15 \mathrm{~min}$ at room temperature. Thereafter cells were stained with Oil Red O solution (Sigma-Aldrich, Munich, Germany) and washed twice with PBS. Lipid droplet formation was analysed by flow cytometry or fluorescence microscopy. For the flow cytometry analyses the fluorescence of $2 \times 10^{4}$ cells was measured at the FL- 2 channel $(488 / 575 \mathrm{~nm})$ with the CyFlowML cytometer (Partec, Münster, Germany). For the fluorescence microscopy analyses the area within the cells was quantified by the use of the Olympus xcellence software (Olympus, Hamburg, Germany) at $546 \mathrm{~nm}$ excitation and $580 \mathrm{~nm}$ emission. For each incubation condition five to seven coincidentally selected images, each containing 30 to 100 cells, were used to quantify the proportion of the lipid droplet area to the total cell area with the phase analysis module of the xcellence software.

Statistical Analysis

Data are expressed as means \pm SEM. Statistical analyses were performed using ANOVA plus Dunnett's or Bonferroni's test for multiple comparisons, unless otherwise stated (Graphpad, San Diego, CA).

\section{Results}

Protective effect of unsaturated NEFAs against the toxicity of palmitic acid in insulinproducing cells

Palmitic acid, the physiologically most abundant saturated NEFA, had a strong cytotoxic effect on RINm5F insulin-producing cells, whereas unsaturated fatty acids showed only a minor toxic effect (Fig. 1A). Moreover, unsaturated NEFAs were protective against the toxicity of long-chain saturated NEFAs. The toxicity of saturated NEFAs is known to be chain-length dependent [9], whereas the structural requirements for the protective effect of unsaturated NEFAs and the mechanism of protection are still unknown. Therefore we analyzed the protective effect of unsaturated NEFAs that differ in the chain length of the carbon scaffold (Fig. 1B). Palmitoleic (C16:1) and oleic (C18:1) acid exhibited a strong protective effect against the toxicity of palmitic acid $(200 \mu \mathrm{M})$ with comparable $\mathrm{EC}_{50}$ values, of $21 \pm 2 \mu \mathrm{M}$ for palmitoleic acid and $22 \pm 2 \mu \mathrm{M}$ for oleic acid. In contrast, the shorter monounsaturated NEFA myristoleic acid (C14:1) had a significantly lower protective effect. Even at a concentration of $200 \mu \mathrm{M}$ myristoleic acid, viability increased only to $47 \pm 3 \%$. With further shortening of the chain length the protective effect was even more reduced. Hence, the viability reached only $18 \pm 2 \%$ after addition of $200 \mu \mathrm{M}$ dodecenoic acid (C12:1). In summary, the protective effect against palmitic acid induced toxicity decreased with shortening of the chain length, with oleic and palmitoleic acid providing the greatest protection (Fig. 1B).

Unsaturated NEFAs that differ in the number of double bonds, oleic acid (C18:1), linoleic acid (C18:2), and $\gamma$-linolenic acid (C18:3), exhibited only a minimal toxic effect upon insulinproducing cells (Fig. 1A). Nevertheless, all unsaturated C18 NEFAs showed a comparable, significant protection against the toxicity of palmitic acid (C16:0) irrespective of the number of double bonds. 
Fig. 1. Protective effect of unsaturated NEFAs against palmitic or pristanic acid induced toxicity in RINm5F insulin-producing cells. A. RINm5F cells were incubated with palmitic acid ( 0 or $200 \mu \mathrm{M}$ ) and unsaturated NEFAs (100 $\mu \mathrm{M})$ which differ in the number of double bonds. B. RINm5F cells were incubated with palmitic acid $(200 \mu \mathrm{M})$ and monounsaturated NEFAs of different chain lenghts. C. RINm5F cells were incubated with pristanic acid (200 $\mu \mathrm{M})$ and different oleic acid concentrations. Cell viability was determined after $24 \mathrm{~h}$ by MTT assay and expressed as a percentage of untreated cells. Data are means \pm SEM from four individual experiments. ${ }^{* *} \mathrm{p}<0.001$ vs. palmitic acid (ANOVA/Dunnett's test for multiple comparisons).

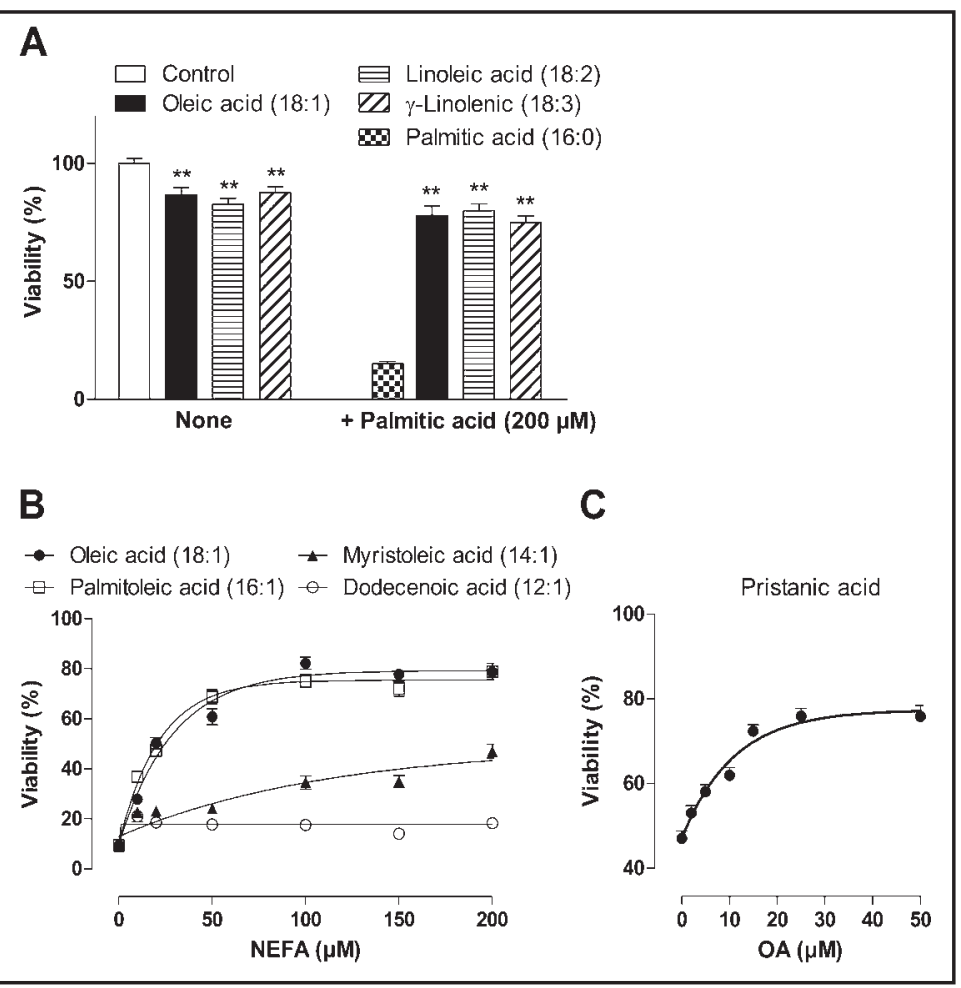

Fig. 2. Ultrastructural alterations in RINm5F cells treated with NEFAs. Shown are representative images of RINm5F insulin-producing cells under control conditions (A) and after $24 \mathrm{~h}$ incubation with palmitic acid $(100 \mu \mathrm{M})(\mathrm{B})$, oleic acid $(100 \mu \mathrm{M})(\mathrm{C})$, or a combination of both (100 $\mu \mathrm{M}$ each) (D). $\gg$ normally developed rough endoplasmic reticulum, $\measuredangle$ changes in the rough endoplasmic reticulum, $*$ mitochondria, $\checkmark$ lipid droplets.

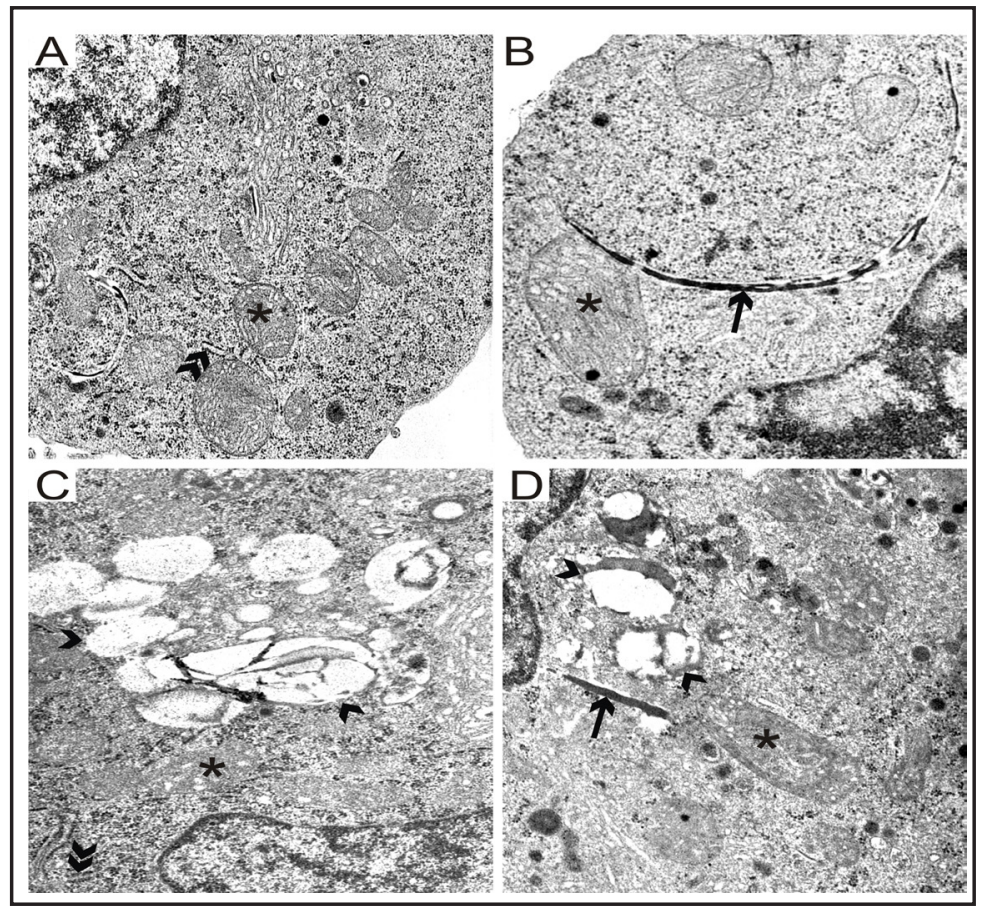

To gain insight into the mechanism of lipotoxicity and the protective effect of unsaturated NEFAs in insulin-producing cells pristanic acid, a branched chain saturated NEFA, which is exclusively metabolized by peroxisomal $\beta$-oxidation, was used. Pristanic acid, like palmitic acid, also showed a distinct toxic effect on insulin-producing cells (47 $\pm 2 \%$ viability at 200 $\mu \mathrm{M}$ pristanic acid). Oleic acid protected against pristanic acid induced toxicity in almost the same concentration-dependent manner as against palmitic acid induced toxicity. These 
Fig. 3. Gene expression analyses of ER stress marker genes in RINm5F insulinproducing cells treated with NEFAs. mRNA expression of the ER stress marker genes Bip (A), XBP-1 (B), CHOP (C), and XBP-1 spliced (D) in RINm5F cells after $6-24 \mathrm{~h}$ treatment with palmitic acid (PA) (100 $\mu \mathrm{M})$, oleic acid $(\mathrm{OA})$ $(100 \mu \mathrm{M})$, or a combination of both $(100 \mu \mathrm{M}$ each) was quantified by qPCR. Expression levels were normalized to the expression of the reference gene cyclophilin (peptidylprolyl isomerase A /

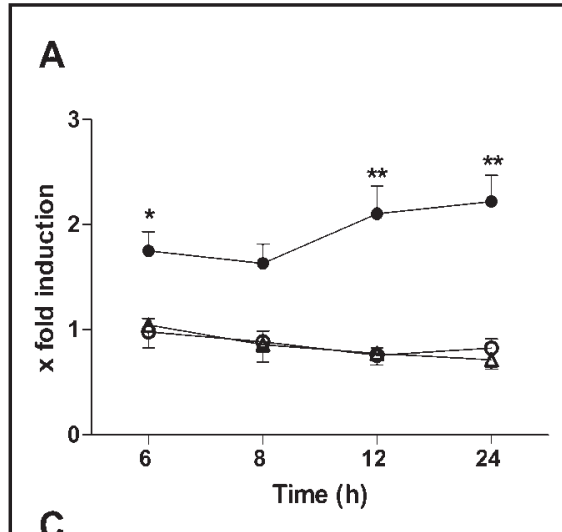

\section{B}

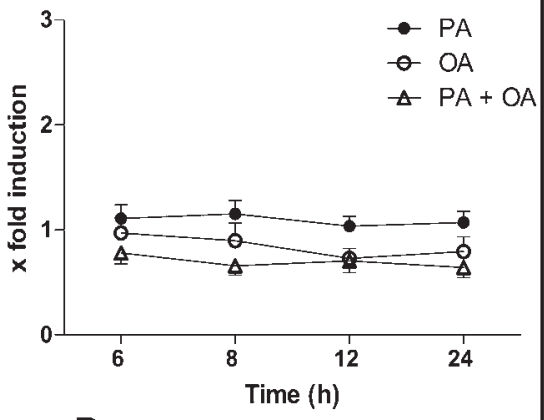

D
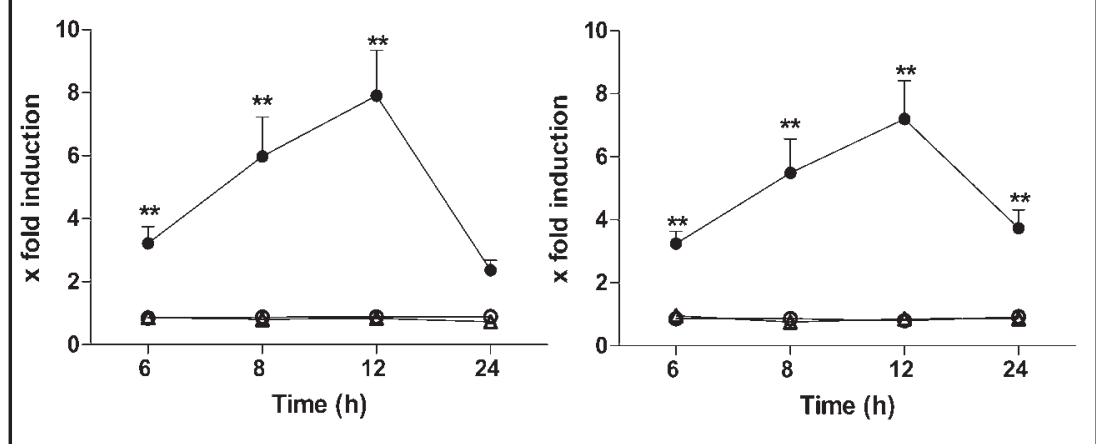

PPIA) and calculated as $x$ fold induction. Results are means \pm SEM from 4-7 individual experiments, ${ }^{*} \mathrm{p}<0.05$, ${ }^{* *} \mathrm{p}<0.01$ compared with untreated cells (ANOVA/Dunnett's-test).

results indicate that the toxicity of saturated fatty acids depends upon the metabolism in peroxisomes (Fig. 1C).

The comparison of the toxic effect of palmitic acid with that of the respective nonmetabolisable methyl derivative revealed that its metabolism is essential for the toxic action. The viability of RINm5F cells after treatment with $200 \mu \mathrm{M}$ palmitic acid decreased significantly to $12 \pm 1 \%$, whereas the viability after incubation with $200 \mu \mathrm{M}$ methylpalmitic acid (palmitic acid methyl ester) was not significantly reduced in comparison to untreated cells $(95 \pm 7 \%)$.

Palmitic acid induced activation of caspase-3

A flow cytometry based caspase- 3 assay was performed to determine the cell death mode of lipotoxicity. Caspase- 3 was significantly activated in RINm5F insulin-producing cells after $24 \mathrm{~h}$ treatment with palmitic acid $(100 \mu \mathrm{M})(30 \pm 4 \%$ vs. $6 \pm 1 \%$ in control cells, $n=4 ; p$ $<0.01)$. By contrast, oleic acid $(100 \mu \mathrm{M})(5 \pm 1 \% ; \mathrm{n}=4)$ did not activate caspase-3. Moreover, oleic acid entirely prevented palmitic acid induced caspase- 3 activation $(6 \pm 1 \% ; n=4)$.

Ultrastructural alterations of insulin-producing cells treated with palmitic and oleic acid

To obtain information upon the morphological changes induced by NEFAs, an ultrastructural analysis by electron microscopy was performed (Fig. 2). After a $24 \mathrm{~h}$ incubation with palmitic acid $(100 \mu \mathrm{M})$ damage to the rough endoplasmic reticulum (ER) was clearly detectable, while at the same time the mitochondria remained intact (Fig. 2B). The cisternae of the ER were elongated and dilated containing dark deposits. When the cells were incubated with oleic acid $(100 \mu \mathrm{M})$, lipid droplets accumulated in the cytoplasm, whereas the ER remained unaffected (Fig. 2C). Only minor accumulation of lipid droplets and damage to the ER were observed after treatment with a mixture of palmitic and oleic 


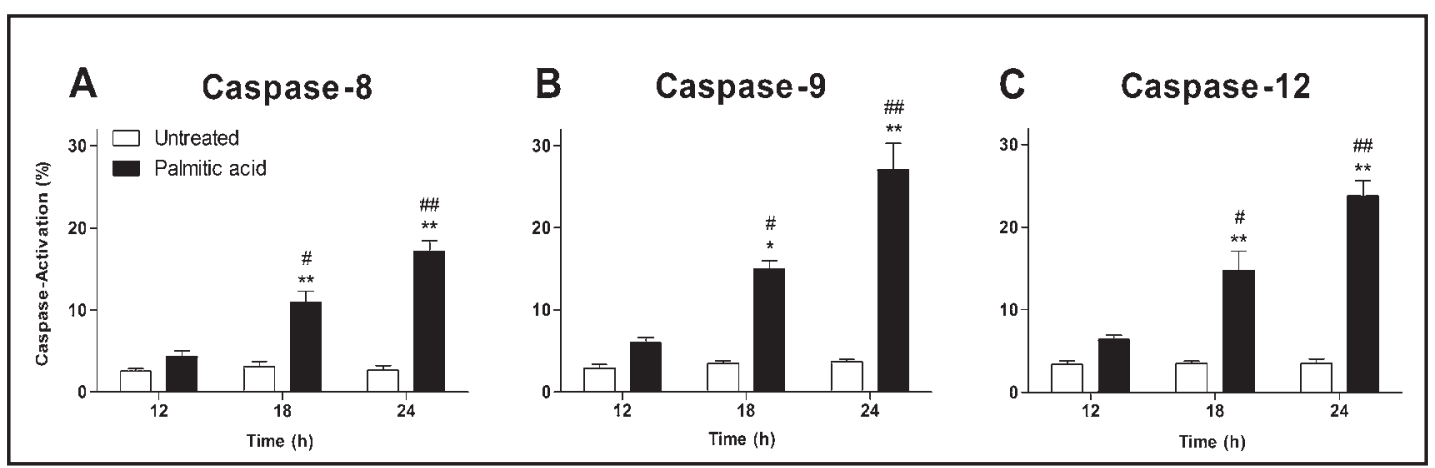

Fig. 4. Activation of initiator caspases in insulin-producing cells by palmitic acid (PA). After 12, 18, and 24 $\mathrm{h}$ treatment with palmitic acid $(100 \mu \mathrm{M})$ activation of caspase-8 (A), -9 (B), and -12 (C) in RINm5F cells was measured by flow cytometry. Data are means \pm SEM from 4-9 individual experiments, ${ }^{*} \mathrm{p}<0.01,{ }^{* *} \mathrm{p}<0.001$ as compared to untreated cells (ANOVA/Dunnett's test); \#p $<0.05$, \#\#p $<0.01$ comparison of $12 \mathrm{~h}$ vs. $18 \mathrm{~h}$ and $18 \mathrm{~h}$ vs. $24 \mathrm{~h}$ (ANOVA/Bonferroni's test).

Fig. 5. Palmitic acid (PA) induced production of reactive oxygen species in RINm5F insulin-producing cells which overexpress catalase in the peroxisomes (Cat) or in the mitochondria (Mito-Cat). To determine ROS generation, cells were loaded with $10 \mu \mathrm{M}$ of DCF-DA dye for 30 min and then cultured with palmitic acid (PA) $(100 \mu \mathrm{M})$, oleic acid (OA) $(100 \mu \mathrm{M})$ or a combination of both $(100 \mu \mathrm{M}$ each $)$ for $24 \mathrm{~h}$. DCF fluorescence was measured after $24 \mathrm{~h}$ and normalized to the cell viability determined by MTT assay.

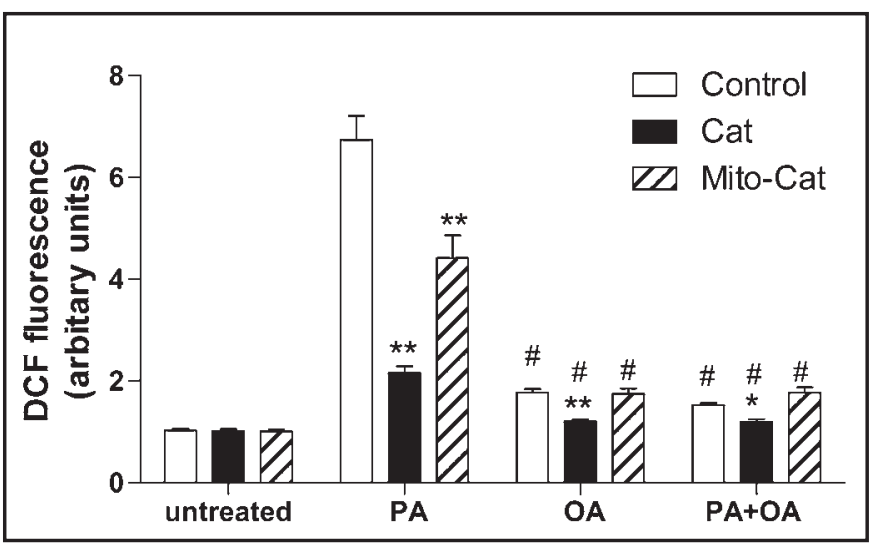

Data are means \pm SEM from seven individual experiments. ${ }^{*} p<0.05,{ }^{* *} p<0.01$ as compared with control cells; $\# \mathrm{p}<0.01$ vs. PA treated cells, (ANOVA/Dunnett's test for multiple comparisons).

acid (Fig. 2D) when compared to control (Fig. 2A). There were no mitochondrial alterations detectable under any of the different experimental conditions.

MRNA expression of the ER stress marker genes

To characterize the underlying mechanism of NEFA induced cell death the gene expression of the ER-stress marker genes X-box binding protein 1 (XBP1), the spliced form of the X-box binding protein 1 (XBP1s), CHOP (C/EBP (CCAAT/enhancer-binding protein)homologous), and the ER chaperone Bip were analysed. Palmitic acid $(100 \mu \mathrm{M})$ induced the expression of the ER stress marker genes CHOP and Bip and also splicing of XBP-1 was markedly induced after palmitic acid incubation with a maximum after $12 \mathrm{~h}$, whereas expression of XBP-1 was not affected (Fig. 3). Oleic acid (100 $\mu \mathrm{M})$ had no effect on the gene expression of any of the analyzed ER stress marker genes (Fig. 3). Moreover, it completely prevented the palmitic acid mediated ER stress gene induction (Fig. 3).

Palmitic acid induced activation of different initiator caspases

To gain a closer insight into the role of different cellular compartments on the NEFA induced apoptosis the activation of death-receptor specific caspase-8, mitochondria specific caspase- 9 and ER specific caspase- 12 were analysed. Gene expression of ER stress marker genes was elevated after $12 \mathrm{~h}$ incubation with palmitic acid $(100 \mu \mathrm{M})$, but did not result in an immediate activation of caspase- 12 . However, the caspases were significantly induced KARGER 


\section{Cellular Physiology Cell Physiol Biochem 2015;36:852-865 \begin{tabular}{c|c|c|}
\hline DOI: 10.1159/000430261 & O 2015 S. Karger AG, Basel
\end{tabular}

Fig. 6. Live cell fluorescence microscopy for detection of $\mathrm{H}_{2} \mathrm{O}_{2}$ in RINm5F insulin-producing cells using the $\mathrm{H}_{2} \mathrm{O}_{2}$ sensor protein HyPer-Peroxi treated with NEFAs. Cells which stably expressed the $\mathrm{H}_{2} \mathrm{O}_{2}$ sensor protein HyPer in peroxisomes (HyPerPeroxi) were incubated under control conditions (A) or with palmitic acid $(100 \mu \mathrm{M})(\mathrm{B})$, oleic acid (100 $\mu \mathrm{M})(\mathrm{C})$, or a combination of both (100 $\mu \mathrm{M}$ each) (D) for $24 \mathrm{~h}$. Shown are representative images of four individual experiments. Fluorescence at $504 / 520 \mathrm{~nm}$ is depicted in red and fluorescence at $427 / 520 \mathrm{~nm}$ is shown in green. Increased $\mathrm{H}_{2} \mathrm{O}_{2}$ generation is indicated by a color change from green to yellow to red.

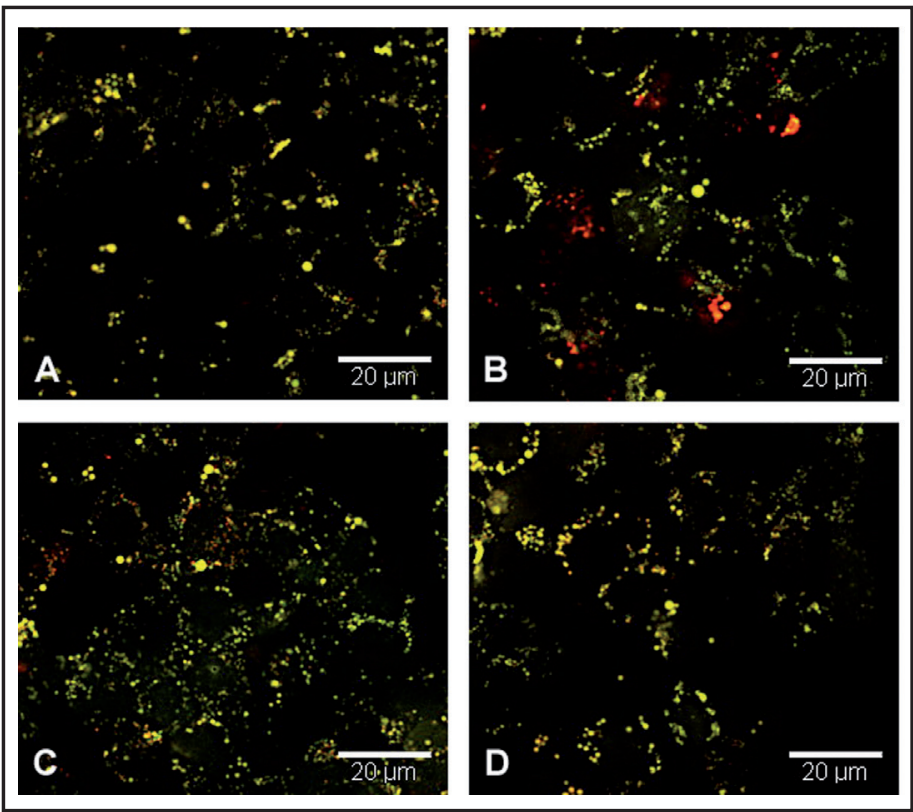

Fig. 7. Peroxisomal $\mathrm{H}_{2} \mathrm{O}_{2}$ production in RINm5F insulin-producing cells treated with NEFAs. Cells which stably expressed the $\mathrm{H}_{2} \mathrm{O}_{2}$ sensor protein HyPer in peroxisomes as well as catalase in the peroxisomes (Cat) or mitochondria (Mito-Cat) were treated with palmitic acid (PA) $(100 \mu \mathrm{M})$, oleic acid $(\mathrm{OA})(100 \mu \mathrm{M})$ or a combination of both (100 $\mu \mathrm{M}$ each) for 24 $\mathrm{h}$. The fluorescence ratio (excitation

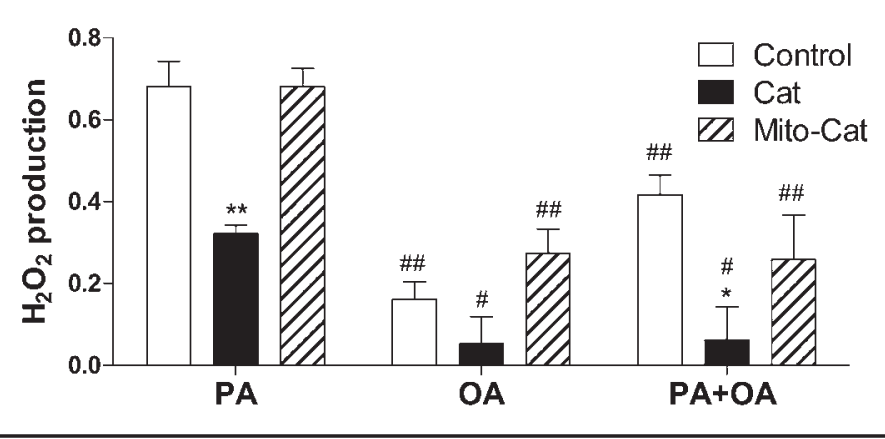
$427 \mathrm{~nm}$ and $475 \mathrm{~nm}$, emission $520 \mathrm{~nm}$ ) indicating the $\mathrm{H}_{2} \mathrm{O}_{2}$ production was measured after $24 \mathrm{~h}$ and normalized to the fluorescence ratio of untreated cells. Data are means \pm SEM from ten individual experiments. *p $<$ $0.05,{ }^{* *} \mathrm{p}<0.01$ vs. control cells, ${ }^{*} \mathrm{p}<0.05$, ${ }^{\# \#} \mathrm{p}<0.01$ vs. PA treated cells, (ANOVA/Dunnett's test for multiple comparisons).

after $18 \mathrm{~h}$ with a further increase at $24 \mathrm{~h}$ (Fig. 4). Remarkably, the induction of all analysed caspases was not different at any time point, indicating that all caspases could be activated by the same upstream effector. In contrast to palmitic acid, oleic acid $(100 \mu \mathrm{M})$ did not induce any of these three caspases $-8,-9$ and -12 , but it reversed the effects of palmitic acid (data not shown).

\section{Oleic acid prevents palmitic acid induced ROS production}

ROS generation observed with the DCF assay was increased approximately 7-fold when RINm5F control cells were treated with palmitic acid (100 $\mu \mathrm{M})$ in comparison to untreated cells, while palmitic acid incubation of RINm5F cells overexpressing catalase in the peroxisome resulted in a merely 2-fold increase in DCF fluorescence (Fig. 5). When catalase was overexpressed in the mitochondria, the ROS production was 4-fold elevated. The pronounced decrease of DCF fluorescence by catalase overexpression indicates that $\mathrm{H}_{2} \mathrm{O}_{2}$ is the main reactive oxygen species formed during incubation with palmitic acid. By contrast ROS generation was only slightly increased after exposure to oleic acid (100 $\mu \mathrm{M})$. Moreover, oleic acid was able to prevent palmitic acid induced ROS generation (Fig. 5). 


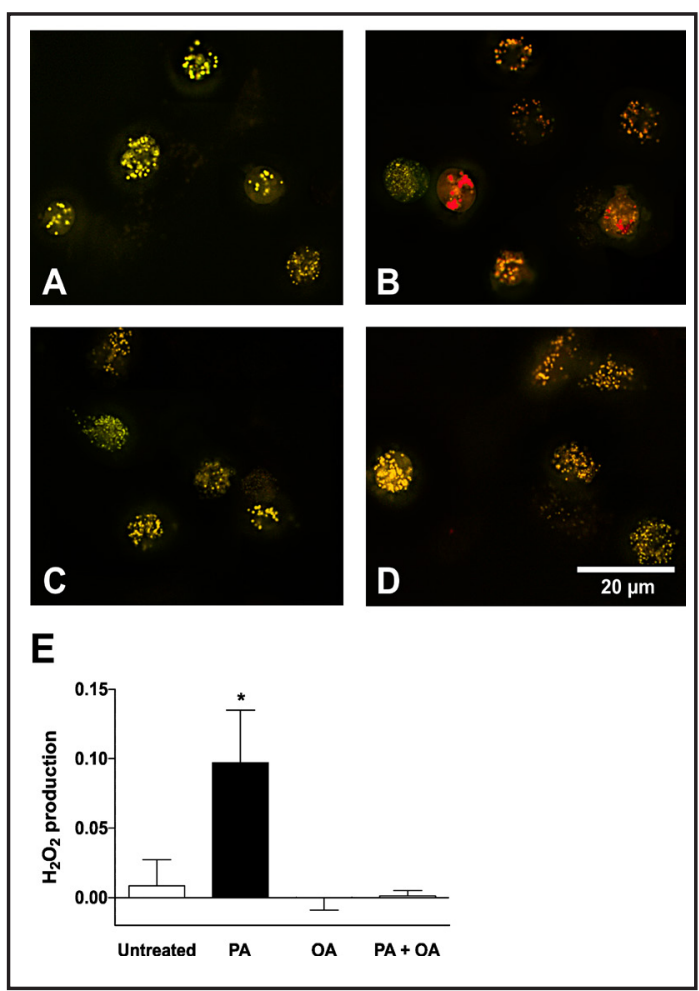

Fig. 8. Peroxisomal $\mathrm{H}_{2} \mathrm{O}_{2}$ production in primary rat islet cells treated with NEFAs. Primary rat islet cells were infected with HyPer-Peroxi lentivirus at a MOI of 10. Islet cells which expressed the $\mathrm{H}_{2} \mathrm{O}_{2}$ sensor protein HyPer in peroxisomes (HyPer-Peroxi) were incubated under control conditions (A) or with palmitic acid (PA) (500 $\mu \mathrm{M})(\mathrm{B})$, oleic acid (OA) (500 $\mu \mathrm{M})(\mathrm{C})$, or a combination of both (500 $\mu \mathrm{M}$ each) (D) for $24 \mathrm{~h}$. (E) To quantify the hydrogen peroxide production images of primary rat islet cells were analysed with the CellR software (Olympus, Hamburg, Germany). The fluorescence intensities of individual cells was measured at 504/520 nm and 427/520 $\mathrm{nm}$. The ratio of both wavelength pairs indicates the $\mathrm{H}_{2} \mathrm{O}_{2}$ production. Shown are the changes in the fluorescence ratios after $24 \mathrm{~h}$. Data are means \pm SEM from three to four individual experiments. ${ }^{*} \mathrm{p}<0.05$ as compared with $\mathrm{H}_{2} \mathrm{O}_{2}$ production of untreated cells.

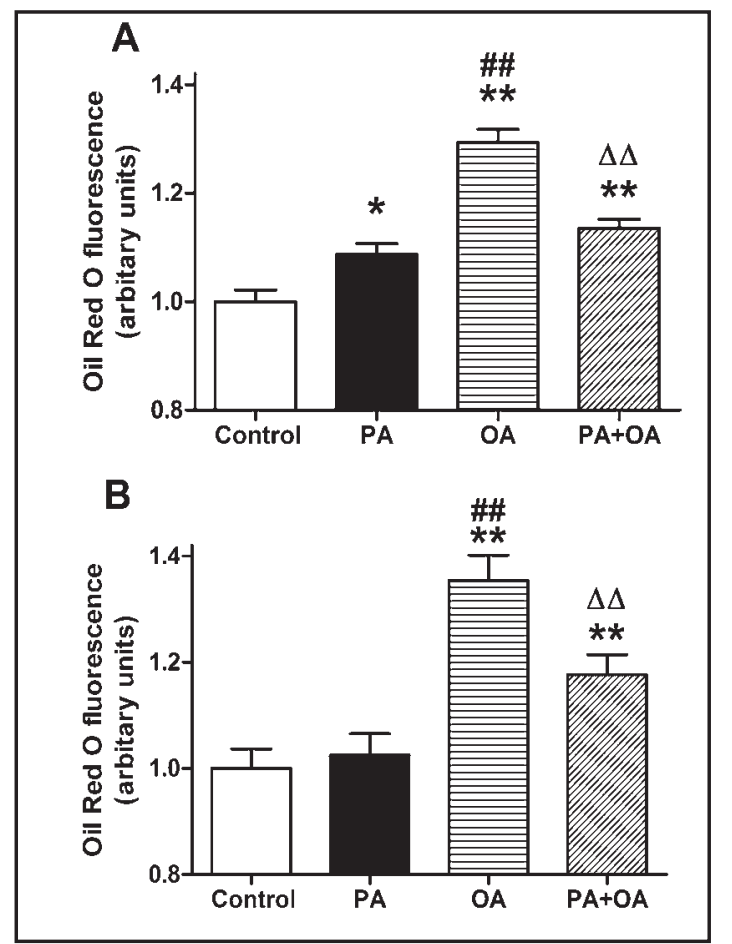

Fig. 9. (A) Oil Red O staining after exposure to nonesterified fatty acids RINm5F insulin-producing cells were treated for $24 \mathrm{~h}$ with either $100 \mu \mathrm{M}$ palmitic acid (PA), $100 \mu \mathrm{M}$ oleic acid (OA) or a combination of both $(100 \mu \mathrm{M}$ each). Afterwards the cells were trypsinised and stained with Oil Red 0 . The number of Oil Red 0 positive cells was quantified by flow cytometry. (B) Primary rat islets were cultivated on ECM tissues culture dishes for one week, incubated with NEFAs and thereafter stained with Oil Red O. To quantify lipid droplet formation in single cells images were analysed with the CellR software (Olympus, Hamburg, Germany). The fluorescence intensities of individual cells were measured at 542/580 nm. Data are means \pm SEM from twelve (A) or four (B) individual experiments. ${ }^{*} \mathrm{p}<0.05$ vs. control cells; ${ }^{* *} \mathrm{p}$ $<0.01$ vs. control cells; ${ }^{\# \#} \mathrm{p}<0.01 \mathrm{OA}$ vs. PA treated cells; ${ }^{\Delta \Delta} \mathrm{p}<0.01 \mathrm{PA}+\mathrm{OA}$ vs. OA treated cells; (ANOVA/ Bonferroni's Multiple Comparison Test).

Peroxisomal $\mathrm{H}_{2} \mathrm{O}_{2}$ generation in primary rat islet cells and insulin-producing RINm5F cells after NEFA exposure

Reduction of DCF by overexpression of catalase suggests that $\mathrm{H}_{2} \mathrm{O}_{2}$ is generated due to palmitic acid treatment. To obtain direct evidence for the $\mathrm{H}_{2} \mathrm{O}_{2}$ formation in a defined subcellular localization the $\mathrm{H}_{2} \mathrm{O}_{2}$ sensor protein HyPer was expressed in primary rat islet cells and RINm5F cells. The HyPer-Peroxi protein containing the signal peptide sequence for peroxisomal import allows ratiometric measurement of $\mathrm{H}_{2} \mathrm{O}_{2}$ by fluorescence microscopy in this organelle. In the false colored images, green staining corresponds to low, yellow to medium, and red to high $\mathrm{H}_{2} \mathrm{O}_{2}$ concentrations. After $24 \mathrm{~h}$ of exposure to palmitic acid

\section{KARGER}




\section{Cellular Physiology Cell Physiol Biochem 2015;36:852-865 \\ \begin{tabular}{l|l} 
DOI: 10.1159/000430261 & (C) 2015 S. Karger AG, Basel
\end{tabular} \\ \begin{tabular}{l|l} 
and Biochemistry Published online: May 27, 2015 & www.karger.com/cpb \\
\cline { 1 - 2 }
\end{tabular} \\ Gehrmann et al.: Oleic Acid Reverses Lipotoxicity}

$(100 \mu \mathrm{M})$, RINm5F-HyPer-Peroxi cells showed a strong shift towards red fluorescence in comparison to untreated cells (Fig. 6A and Fig. 6B), whereas the cells exposed to oleic acid $(100 \mu \mathrm{M})$ showed a fluorescence signal similar to that of untreated cells (Fig. 6C). Moreover, oleic acid prevented the strong fluorescence shift towards red observed after palmitic acid treatment (Fig. 6D).

The $\mathrm{H}_{2} \mathrm{O}_{2}$ generation in the peroxisomes following exposure to NEFAs was quantified spectrofluorometrically. The $\mathrm{H}_{2} \mathrm{O}_{2}$ concentration after oleic acid treatment was significantly lower than after palmitic acid treatment (Fig. 7). Moreover, as observed with the DCF assay, oleic acid reduced palmitic acid induced $\mathrm{H}_{2} \mathrm{O}_{2}$ generation (Fig. 7). Further evidence that the peroxisomes were the subcellular site of $\mathrm{H}_{2} \mathrm{O}_{2}$ formation arises from the fact that only catalase in the peroxisomes significantly reduced $\mathrm{H}_{2} \mathrm{O}_{2}$ formation, whereas overexpression of catalase in the mitochondria had no effect. The mitochondrial $\mathrm{H}_{2} \mathrm{O}_{2}$ generation observed with the HyPer protein located in the mitochondria showed no significant changes following exposure to palmitic acid, oleic acid or a mixture of both (data not shown).

Primary rat islet cells expressing HyPer-Peroxi were treated for $24 \mathrm{~h}$ with palmitic acid $(500 \mu \mathrm{M})$, oleic acid $(500 \mu \mathrm{M})$ or a mixture of palmitic and oleic acid (500 $\mu \mathrm{M}$ each) (Fig. 8 ). The hydrogen peroxide production was analysed by fluorescence microscopy and the fluorescence signal of individual cells was quantified with the CellR software (Olympus). After a $24 \mathrm{~h}$ incubation with palmitic acid the hydrogen peroxide production increased 10 fold in comparison to untreated cells while oleic acid treatment did not result in a significant increase in hydrogen peroxide production (Fig. 8). Moreover, oleic acid was able to prevent the palmitic acid mediated induction of hydrogen peroxide production (Fig. 8).

\section{Effect of oleic and palmitic acid on lipid droplet formation}

Incubation with $100 \mu \mathrm{M}$ oleic acid lead to significant NEFA accumulation by lipid droplet formation in RINm5F as well as in primary rat islet cells (Fig. 9). In RINm5F cells PA increased the lipid droplet content slightly (by 9\%) (Fig. 9A). In primary rat islet cells PA showed no significant effect on lipid droplet content (Fig. 9B). Interestingly the lipid droplet formation induced by $\mathrm{OA}$ in RINm5F and primary rat islet cells was significantly reduced in co-incubation experiments with PA (Fig. 9). These quantitative data agree with those of the ultrastructural analyses (Fig. 2).

\section{Discussion}

Hyperlipidaemia is a major risk factor for the development of type 2 diabetes mellitus $[35,36]$. Elevated levels of non-esterified fatty acids (NEFAs) are under suspicion to mediate $\beta$-cell dysfunction and $\beta$-cell loss $[5,37,38]$. However, not only the total concentration of NEFAs is crucial for these deleterious effects but also the ratio of saturated to unsaturated NEFAs [39]. In the present study we analysed the protective effect of different unsaturated NEFAs against the toxicity of palmitic acid, the physiologically most abundant saturated fatty acid. According to earlier observations $[8,19]$ unsaturated fatty acids are able to counteract the ability of saturated fatty acids to induce $\beta$-cell apoptosis, but the underlying mechanisms remain unknown. It has been proposed that increased $\beta$-oxidation and oxidative phosphorylation cause lipotoxicity by enhanced formation of reactive oxygen species (ROS) in the mitochondria $[15,16,40]$ or alternatively in the peroxisomes $[9,41]$. For the detoxification of $\mathrm{H}_{2} \mathrm{O}_{2}$, the oxidoreductase catalase is expressed in the peroxisomes of most tissues [42,43], but not in those of pancreatic $\beta$-cells $[23,44]$. This low catalase enzyme activity could also be found in insulin-producing RINm5F cells. This makes these cells well suited as model cells for studies on $\mathrm{H}_{2} \mathrm{O}_{2}$-mediated lipotoxicity and the particular sensitivity of insulin-producing cells towards oxidative stress.

Initially we analysed the ROS formation by a DCF assay in RINm5F cells overexpressing the $\mathrm{H}_{2} \mathrm{O}_{2}$ detoxifying enzyme catalase either in the mitochondria or in the peroxisomes. While palmitic acid caused a strong increase of ROS formation the effect of oleic acid was negligible. 


\section{Cellular Physiology Cell Physiol Biochem 2015;36:852-865 \\ \begin{tabular}{l|l} 
and Biochemistry Published online: May 27, 2015 & $\begin{array}{l}\text { C 2015 S. Karger AG, Basel } \\
\text { www.karger.com/cpb }\end{array}$ \\
\hline
\end{tabular} \\ Gehrmann et al.: Oleic Acid Reverses Lipotoxicity}

Moreover, oleic acid was even able to suppress palmitic acid induced ROS formation. The reduced ROS formation in catalase overexpressing cells indicates that $\mathrm{H}_{2} \mathrm{O}_{2}$ is the deleterious reactive oxygen species. As shown before [9], this effect was much more pronounced when the catalase was overexpressed in the peroxisomes than in the mitochondria.

NEFAs are not only metabolized through mitochondrial $\beta$-oxidation but, in particular long-chain NEFAs, are substrates for peroxisomal $\beta$-oxidation [45-47]. In contrast to the mitochondrial $\beta$-oxidation, the acyl-CoA oxidases in the peroxisomes form $\mathrm{H}_{2} \mathrm{O}_{2}$ rather than reducing equivalents [48]. $\mathrm{H}_{2} \mathrm{O}_{2}$ can easily disproportionate by the metal-catalysed Fenton reaction to the highly reactive hydroxyl radical $[49,50]$.

In order to obtain direct evidence for $\mathrm{H}_{2} \mathrm{O}_{2}$ generation in a defined subcellular localization we used the fluorescence sensor protein HyPer. An increase of the peroxisomal $\mathrm{H}_{2} \mathrm{O}_{2}$ concentration was detectable in insulin-producing RINm5F cells as well as in primary pancreatic islet cells after exposure to palmitic acid. This increased peroxisomal $\mathrm{H}_{2} \mathrm{O}_{2}$ production was suppressed in the presence of oleic acid. Additional evidence for the contribution of peroxisomal fatty acid metabolism to the lipotoxicity in insulin-producing cells was provided by the toxicity of pristanic acid, a branched chain saturated fatty acid, which is exclusively metabolized in the peroxisomes [45, 47]. Oleic acid protected also against pristanic acid mediated toxicity in a concentration-dependent manner like against that of palmitic acid. The protective effect of unsaturated NEFAs was independent of the number of double bonds, indicating that the mechanism was not dependent on the radical scavenging capability of the double bond.

Another proposed mechanism for lipotoxicity has been the induction of ER stress [12, 51], which ultimately resulted in apoptosis through CHOP activation. The damage to the ER observed in the present ultrastructural analyses provides support for such a contention. Palmitic acid induced expression of ER stress marker genes was fully suppressed by oleic acid. The observation that ER specific caspase- 12 was activated to almost the same extent and over the same time course as the initiator caspases- 8 and -9 , questions the role of ER stress as a primary mediator of lipotoxicity. This equal activation including that of the mitochondria specific caspase-9 indicates that the mitochondria are not a primary site for the initiation of oxidative stress mediated lipotoxicity. This conclusion is in accordance with our recent observation [9] that peroxisomally generated $\mathrm{H}_{2} \mathrm{O}_{2}$ rather than mitochondrially generated $\mathrm{H}_{2} \mathrm{O}_{2}$ mediates lipotoxicity.

In contrast to palmitic acid, which was found to form TG depots in vacuoles of expanded endoplasmic reticulum confirming earlier observations $[19,26,52]$, oleic acid induced cytosolic lipid droplet formation outside the ER, apparently due to its efficient esterification to triglycerides $[19,26,52,53]$.

Through this sequestration and deposition of triglycerides in lipid droplets [19] unsaturated fatty acids such as oleic acid may not be available for peroxisomal $\beta$-oxidation thereby avoiding $\mathrm{H}_{2} \mathrm{O}_{2}$ formation. If this hypothesis for the protective mechanism would be correct, a co-incubation of palmitic and oleic acid should led to an increase in lipid droplet formation. However, our experiments revealed just the opposite result. Palmitic acid reduced oleic acid induced lipid droplet formation to the level of the control condition. This result is remarkable in view of the fact that in the co-incubation experiments the total NEFA concentration was doubled. It is therefore a question whether this sequestration by long-term storage of fatty acids in the form of triglycerides may be beneficial for pancreatic $\beta$-cells. Not least, because a number of diseases affecting other tissues such as non-alcoholic fatty liver disease [54] or cardiovascular disease have been associated to intracellular fat accumulation [55].

In conclusion, palmitic acid induced $\mathrm{H}_{2} \mathrm{O}_{2}$ formation by peroxisomal $\beta$-oxidation resulting in $\beta$-cell apoptosis, whereas oleic acid prevented this $\mathrm{H}_{2} \mathrm{O}_{2}$ formation due to antagonizing palmitic acid induced $\mathrm{H}_{2} \mathrm{O}_{2}$ formation in peroxisomal $\beta$-oxidation in rat insulin-producing RINm5F cells and primary rat islet cells. The results indicate that unsaturated fatty acids in the lipid component of the diet can help to prevent lipotoxicity-mediated deterioration of glucose tolerance ultimately resulting in the manifestation of type 2 diabetes. 


\begin{tabular}{|c|c|c|}
\hline Cellular Physiology & Cell Physiol Biochem 2015;36:852-865 & \\
\hline and Biochemistry & $\begin{array}{l}\text { DOI: 10.1159/000430261 } \\
\text { Published online: May 27, } 2015\end{array}$ & $\begin{array}{l}\text { O } 2015 \mathrm{~S} \text {. Karger AG, Basel } \\
\text { www.karger.com/cpb }\end{array}$ \\
\hline
\end{tabular}

\section{Abbreviations}

DCF-DA (2 7 -dichlorofluorescein diacetate); $\mathrm{EC}_{50}$ (half maximally effective concentration); ER (endoplasmic reticulum); $\mathrm{H}_{2} \mathrm{O}_{2}$ (hydrogen peroxide); MOI (multiplicity of infection); MTT (3-(4,5-dimethylthiazol-2-yl)-2,5-diphenyl tetrazolium bromide); NEFAs (non-esterified fatty acids); OA (oleic acid); PA (palmitic acid); ROS (reactive oxygen species); TG (triglyceride).

\section{Acknowledgements}

We are grateful to Maren Böger and Martin Wirth for their skillful technical assistance. This work was supported by the European Union (Collaborative Project BetaBAT in the Framework Programme 7, grant agreement 277713).

\section{Disclosure Statement}

The authors declare that there is no duality of interest associated with this study.

\section{References}

1 Roche HM, Phillips C, Gibney MJ: The metabolic syndrome: The crossroads of diet and genetics. Proc Nutr Soc 2005;64:371-377.

2 Sabin MA, De Hora M, Holly JM, Hunt LP, Ford AL, Williams SR, Baker JS, Retallick CJ, Crowne EC, Shield JP: Fasting nonesterified fatty acid profiles in childhood and their relationship with adiposity, insulin sensitivity, and lipid levels. Pediatrics 2007;120:1426-1433.

3 Unger RH: Lipotoxicity in the pathogenesis of obesity-dependent niddm. Genetic and clinical implications. Diabetes 1995;44:863-870.

4 Puzziferri N, Roshek TB, 3rd, Mayo HG, Gallagher R, Belle SH, Livingston EH: Long-term follow-up after bariatric surgery: A systematic review. Jama 2014;312:934-942.

5 Bergman RN, Ader M: Free fatty acids and pathogenesis of type 2 diabetes mellitus. Trends Endocrinol Metab 2000;11:351-356.

6 Boden G, Shulman GI: Free fatty acids in obesity and type 2 diabetes: Defining their role in the development of insulin resistance and beta-cell dysfunction. Eur J Clin Invest 2002;32 Suppl 3:14-23.

7 Rahier J, Guiot Y, Goebbels RM, Sempoux C, Henquin JC: Pancreatic beta-cell mass in european subjects with type 2 diabetes. Diabetes Obes Metab 2008;10 Suppl 4:32-42.

8 Dhayal S, Welters HJ, Morgan NG: Structural requirements for the cytoprotective actions of monounsaturated fatty acids in the pancreatic beta-cell line, brin-bd11. Br J Pharmacol 2008;153:1718-1727.

9 Elsner M, Gehrmann W, Lenzen S: Peroxisome-generated hydrogen peroxide as important mediator of lipotoxicity in insulin-producing cells. Diabetes 2011;60:200-208.

10 Yan W, Wang Y, Xiao Y, Wen J, Wu J, Du L, Cai W: Palmitate induces trb3 expression and promotes apoptosis in human liver cells. Cellular Physiology and Biochemistry 2014;33:823-834.

11 Němcová-Fürstová V, Balušíková K, Šrámek J, James RF, Kovář J: Caspase-2 and jnk activated by saturated fatty acids are not involved in apoptosis induction but modulate er stress in human pancreatic $\beta$-cells. Cellular Physiology and Biochemistry 2013;31:277-289.

12 Kharroubi I, Ladriere L, Cardozo AK, Dogusan Z, Cnop M, Eizirik DL: Free fatty acids and cytokines induce pancreatic beta-cell apoptosis by different mechanisms: Role of nuclear factor-kappab and endoplasmic reticulum stress. Endocrinology 2004;145:5087-5096.

13 Lai E, Bikopoulos G, Wheeler MB, Rozakis-Adcock M, Volchuk A: Differential activation of er stress and apoptosis in response to chronically elevated free fatty acids in pancreatic beta-cells. Am J Physiol Endocrinol Metab 2008;294:E540-550.

14 Murphy MP: How mitochondria produce reactive oxygen species. Biochem J 2009;417:1-13. 


\section{Cellular Physiology Cell Physiol Biochem 2015;36:852-865 \begin{tabular}{l|l|l}
\hline DOI: 10.1159/000430261 & (C) 2015 S. Karger AG, Basel
\end{tabular} www.karger.com/cpb \\ Gehrmann et al.: Oleic Acid Reverses Lipotoxicity}

15 Newsholme P, Haber EP, Hirabara SM, Rebelato EL, Procopio J, Morgan D, Oliveira-Emilio HC, Carpinelli AR, Curi R: Diabetes associated cell stress and dysfunction: Role of mitochondrial and non-mitochondrial ROS production and activity. J Physiol 2007;583:9-24.

16 Schönfeld P, Wojtczak L: Fatty acids as modulators of the cellular production of reactive oxygen species. Free Radic Biol Med 2008;45:231-241.

17 Lambertucci RH, Leandro CG, Vinolo MA, Nachbar RT, dos Reis Silveira L, Hirabara SM, Curi R, PithonCuri TC: The effects of palmitic acid on nitric oxide production by rat skeletal muscle: Mechanism via superoxide and inos activation. Cellular Physiology and Biochemistry 2012;30:1169-1180.

18 Newsholme P, Keane D, Welters HJ, Morgan NG: Life and death decisions of the pancreatic beta-cell: The role of fatty acids. Clin Sci (Lond) 2007;112:27-42.

19 Moffitt JH, Fielding BA, Evershed R, Berstan R, Currie JM, Clark A: Adverse physicochemical properties of tripalmitin in beta cells lead to morphological changes and lipotoxicity in vitro. Diabetologia 2005;48:1819-1829.

20 Eitel K, Staiger H, Brendel MD, Brandhorst D, Bretzel RG, Haring HU, Kellerer M: Different role of saturated and unsaturated fatty acids in beta-cell apoptosis. Biochem Biophys Res Commun 2002;299:853-856.

21 Welters HJ, Tadayyon M, Scarpello JH, Smith SA, Morgan NG: Mono-unsaturated fatty acids protect against beta-cell apoptosis induced by saturated fatty acids, serum withdrawal or cytokine exposure. FEBS Lett 2004;560:103-108.

22 Borg J, Klint C, Wierup N, Strom K, Larsson S, Sundler F, Lupi R, Marchetti P, Xu G, Kimmel A, Londos C, Holm C: Perilipin is present in islets of langerhans and protects against lipotoxicity when overexpressed in the beta-cell line ins-1. Endocrinology 2009;150:3049-3057.

23 Tiedge M, Lortz S, Drinkgern J, Lenzen S: Relation between antioxidant enzyme gene expression and antioxidative defense status of insulin-producing cells. Diabetes 1997;46:1733-1742.

24 Gurgul E, Lortz S, Tiedge M, Jörns A, Lenzen S: Mitochondrial catalase overexpression protects insulinproducing cells against toxicity of reactive oxygen species and proinflammatory cytokines. Diabetes 2004;53:2271-2280.

25 Lortz S, Gurgul-Convey E, Lenzen S, Tiedge M: Importance of mitochondrial superoxide dismutase expression in insulin-producing cells for the toxicity of reactive oxygen species and proinflammatory cytokines. Diabetologia 2005;48:1541-1548.

26 Cnop M, Hannaert JC, Hoorens A, Eizirik DL, Pipeleers DG: Inverse relationship between cytotoxicity of free fatty acids in pancreatic islet cells and cellular triglyceride accumulation. Diabetes 2001;50:1771-1777.

27 Mosmann T: Rapid colorimetric assay for cellular growth and survival: Application to proliferation and cytotoxicity assays. J Immunol Methods 1983;65:55-63.

28 Naujok O, Francini F, Picton S, Bailey CJ, Lenzen S, Jörns A: Changes in gene expression and morphology of mouse embryonic stem cells on differentiation into insulin-producing cells in vitro and in vivo. Diabetes Metab Res Rev 2009;25:464-476.

29 Rosenkranz AR, Schmaldienst S, Stuhlmeier KM, Chen W, Knapp W, Zlabinger GJ: A microplate assay for the detection of oxidative products using 2',7'-dichlorofluorescin-diacetate. J Immunol Methods 1992;156:3945 .

30 de Hoop MJ, Ab G: Import of proteins into peroxisomes and other microbodies. Biochem J 1992;286:657669.

31 Subramani S: Protein import into peroxisomes and biogenesis of the organelle. Annu Rev Cell Biol 1993;9:445-478.

32 Gehrmann W, Elsner M: A specific fluorescence probe for hydrogen peroxide detection in peroxisomes. Free Radic Res 2011;45:501-506.

33 Zufferey R, Dull T, Mandel RJ, Bukovsky A, Quiroz D, Naldini L, Trono D: Self-inactivating lentivirus vector for safe and efficient in vivo gene delivery. J Virol 1998;72:9873-9880.

34 Sastry L, Johnson T, Hobson MJ, Smucker B, Cornetta K: Titering lentiviral vectors: Comparison of DNA, rna and marker expression methods. Gene Ther 2002;9:1155-1162.

35 Burke JP, Williams K, Gaskill SP, Hazuda HP, Haffner SM, Stern MP: Rapid rise in the incidence of type 2 diabetes from 1987 to 1996: Results from the san antonio heart study. Arch Intern Med 1999;159:14501456. 


\section{Cellular Physiology Cell Physiol Biochem 2015;36:852-865 \begin{tabular}{l|l} 
DOI: 10.1159/000430261 & (C) 2015 S. Karger AG, Basel
\end{tabular} www.karger.com/cpb \\ Gehrmann et al.: Oleic Acid Reverses Lipotoxicity}

36 Hull RL, Kodama K, Utzschneider KM, Carr DB, Prigeon RL, Kahn SE: Dietary-fat-induced obesity in mice results in beta cell hyperplasia but not increased insulin release: Evidence for specificity of impaired beta cell adaptation. Diabetologia 2005;48:1350-1358.

37 Butler AE, Janson J, Bonner-Weir S, Ritzel R, Rizza RA, Butler PC: Beta-cell deficit and increased beta-cell apoptosis in humans with type 2 diabetes. Diabetes 2003;52:102-110.

38 Zhou YP, Grill VE: Long-term exposure of rat pancreatic islets to fatty acids inhibits glucose-induced insulin secretion and biosynthesis through a glucose fatty acid cycle. J Clin Invest 1994;93:870-876.

39 Laaksonen DE, Lakka TA, Lakka HM, Nyyssonen K, Rissanen T, Niskanen LK, Salonen JT: Serum fatty acid composition predicts development of impaired fasting glycaemia and diabetes in middle-aged men. Diabet Med 2002;19:456-464.

40 Carlsson C, Borg LA, Welsh N: Sodium palmitate induces partial mitochondrial uncoupling and reactive oxygen species in rat pancreatic islets in vitro. Endocrinology 1999;140:3422-3428.

41 Fransen M, Nordgren M, Wang B, Apanasets O: Role of peroxisomes in ROS/RNS-metabolism: Implications for human disease. Biochim Biophys Acta 2012;1822:1363-1373.

42 Dansen TB, Wirtz KW: The peroxisome in oxidative stress. IUBMB Life 2001;51:223-230.

43 Nordgren M, Fransen M: Peroxisomal metabolism and oxidative stress. Biochimie 2014;98:56-62.

44 Lenzen S, Drinkgern J, Tiedge M: Low antioxidant enzyme gene expression in pancreatic islets compared with various other mouse tissues. Free Radic Biol Med 1996;20:463-466.

45 Kunau WH, Dommes V, Schulz H: Beta-oxidation of fatty acids in mitochondria, peroxisomes, and bacteria: A century of continued progress. Prog Lipid Res 1995;34:267-342.

46 Wanders RJ, Waterham HR: Biochemistry of mammalian peroxisomes revisited. Annu Rev Biochem 2006;75:295-332.

47 Van Veldhoven PP: Biochemistry and genetics of inherited disorders of peroxisomal fatty acid metabolism. J Lipid Res 2010;51:2863-2895.

48 Poirier Y, Antonenkov VD, Glumoff T, Hiltunen JK: Peroxisomal beta-oxidation - a metabolic pathway with multiple functions. Biochim Biophys Acta 2006;1763:1413-1426.

49 Halliwell B, Gutteridge JMC: Free radicals in biology and medicine, ed Fourth Edition. Oxford University Press, 2007.

50 Lenzen S: Oxidative stress: The vulnerable beta-cell. Biochem Soc Trans 2008;36:343-347.

51 Diakogiannaki E, Welters HJ, Morgan NG: Differential regulation of the endoplasmic reticulum stress response in pancreatic beta-cells exposed to long-chain saturated and monounsaturated fatty acids. J Endocrinol 2008;197:553-563.

52 Listenberger LL, Han X, Lewis SE, Cases S, Farese RV Jr, Ory DS, Schaffer JE: Triglyceride accumulation protects against fatty acid-induced lipotoxicity. PNAS 2003;100:3077-3082.

53 Garbarino J, Padamsee M, Wilcox L, Oelkers PM, D'Ambrosio D, Ruggles KV, Ramsey N, Jabado 0, Turkish A, Sturley SL: Sterol and diacylglycerol acyltransferase deficiency triggers fatty acid-mediated cell death. J Biol Chem 2009;284:30994-31005.

54 Parekh S, Anania FA: Abnormal lipid and glucose metabolism in obesity: Implications for nonalcoholic fatty liver disease. Gastroenterology 2007;132:2191-2207.

55 Kienesberger PC, Pulinilkunnil T, Nagendran J, Dyck JR: Myocardial triacylglycerol metabolism. J Mol Cell Cardiol 2013;55:101-110. 